Ильина Ирина Львовна,
к.т.н., доцент, Ангарский государственный технический университет
e-mail: Ilyina_agta@mail.ru

Ерлыков Роман Александрович, магистрант, Ангарский государственный технический университет

МОДЕРНИЗАЦИЯ СИСТЕМЫ УПРАВЛЕНИЯ ПРОЦЕССАМИ СИНТЕЗА МЕТИЛАМИНОВ И ВЫДЕЛЕНИЯ ТОВАРНОГО ДИМЕТИЛАМИНА

\title{
Ilyina I.L., Erlykov R.A. \\ MODERNIZATION OF PROCESS CONTROL FOR THE SYNTHESIS OF METHYLAMINES AND ALLOCATION OF COMMODITY DIMETHYLAMINE
}

\begin{abstract}
Аннотация. Целью работы является повышение эффрективности ведения технологического режима, а также постоянный контроль качества выпускаемой продукции за счет разработки системы управления и ПАЗ на базе электронных средств контроля и автоматики, функционирующих независимо друг от друга и соответствующих требованию законодательства в области промышленной безопасности.

Ключевые слова: эффеектиность ведения технологического режима, модернизация автоматической системы, контроль качества, обеспечение безопасности.

Abstract. Improving the efficiency of the technological regime, as well as continuous quality control of products. Development of the control system and the emergency protection on the basis of electronic control and automation, operating independently of each other and meeting the requirements of legislation in the field of industrial safety.
\end{abstract} trol, safety.

Keywords: efficiency of technological regime, modernization of automatic system, quality con-

Производство метиламинов АО «АНХК» введено в работу в 1960 году и предназначено для получения товарных продуктов: монометиламина, диметиламина, триметиламина, водного раствора диметиламина и отгрузки их потребителям. Метиламины имеют очень широкую область применения. Они используются для синтеза красителей, фармацевтических препаратов, в сельской промышленности, а также применяются в производстве резины. На сегодняшний день мировое производство аминов приближается к 1 млн тонн в год.

Существующая в настоящее время система управления производством построена на системе пневмоавтоматики, морально и физически устаревшей и не позволяющей реализовать функции, соответствующие требованиям, предъявляемым к современным системам управления технологическими процессами.

Установка относится к категории А пожароопасности и имеет в своем составе блоки I и II категорий взрывоопасности, поэтому система автоматизации должна соответствовать Федеральным нормам и правилам в области промышленной безопасности «Общие правила взрывобезопасности для взрывопожароопасных химических, нефтехимических и нефтеперерабатывающих производств».

Опасные производственные объекты, имеющие в своем составе объекты с технологическими блоками I и II категорий взрывоопасности, должны оснащаться автоматическими или автоматизированными системами управления, 
построенными на базе электронных средств контроля и автоматики, включая средства вычислительной техники.

В работе рассмотрен блок синтеза метиламинов, состоящий из реакционной колонны, теплообменника и холодильника, которые предназначены для каталитического аминирования метанола в паровой фазе, а также блок ректифрикационных колонн, предназначенных для получения товарных продуктов [1].

Современное законодательство предъявляет строгие требования к управлению технологическим оборудованием:

- нагревательные трубчатые печи должны быть оборудованы сигнализаторами погасания пламени, надежно регистрирующими наличие пламени в форсунке, блокировками, прекращающими поступление газообразного топлива и воздуха при снижении их давления ниже установленных параметров, средствами автоматического отключения подачи сырья, средствами сигнализации о падении давления в системах подачи сырья;

- насосы, применяемые для нагнетания, должны оснащаться блокировками, исключающими пуск или прекращающими работу насоса при отсутствии перемещаемой жидкости в его корпусе или отклонениях ее уровней в приемной и расходной емкостях от предельно допустимых значений;

- колонны ректификации должны быть оснащены средствами контроля и автоматического регулирования уровня и температуры жидкости в кубовой части, температуры поступающих на разделение продукта и фрлегмы, а также средствами сигнализации об опасных отклонениях значений параметров, в том числе перепада давления между нижней и верхней частями колонны, определяющих взрывобезопасность процесса [2].

Целью работы является разработка системы управления процессом получения товарного диметиламина, обеспечивающей получение товарного продукта требуемого качества и соответствующей всем требованиям по обеспечению безопасности.

При разработке системы управления необходимо решить задачи:

- определения функций распределенной системы управления;

- определения функций системы противоаварийной защиты;

- реализации непрерывного контроля качества выпускаемой продукции.

\section{ЛИТЕРАТУРА}

1. Технологический регламент производства метиламинов цеха 20/23-71 Производства нефтехимии АО «АНХК».

2. Общие правила взрывобезопасности для взрывопожароопасных химических, нефтехимических и нефтеперерабатывающих производств [Электронный ресурс] : приказ Ростехнадзора об утверждении Федеральных норм и правил в области промышленной безопасности от 11 марта 2013 г. № 96. Режим доступа: http://www.gosnadzor.ru/ 